\title{
Review of Diabetic Foot Complication Assessment Tools Developed from 2007 to 2016
}

\author{
Lee, Yoonhee ${ }^{1)} \cdot$ Song, Youngshin ${ }^{2)}$
}

\author{
1) Professor, Department of Nursing, Woosong College, Daejeon \\ 2) Professor, College of Nursing, Chungnam National University, Daejeon, Korea
}

\begin{abstract}
Purpose: The purpose of this study was to analyze the attributes and psychometric properties of newly developed diabetic foot complication assessment tools. The attributes of diabetic foot complication assessment tools were evaluated using a systematic review. Methods: The search terms: "diabetes mellitus" and "foot ulcer" were retrieved using Boolean operators of "and", "or", and "not". The search was limited to articles published between 2007 and 2016. The literature was analyzed by division of methodological characteristics, instrumental characteristics, and item and stratified outcome characteristics. Results: Six assessment tools were found for diabetic foot complications. Only three of the six tools presented the evidence in terms of validity and reliability. In all six tools, "ulcer" was the measured item with the highest frequency, but the contents of items varied. The six identified tools focused on assessing current physical symptoms, but not on predicting diabetic foot complications. Conclusion: Preventive foot self-care should be used to predict diabetic foot complications before symptoms appear. Moreover, the reliability and validity of existing tools should be verified in terms of discrimination, prediction, and evaluation.
\end{abstract}

Key Words: Diabetic foot; Diabetes complication; Risk assessment; Review

*This research was supported by the Basic Science Research Program through the National Research Foundation of Korea (NRF) funded by the Ministry of Education (grant number: 2019R1A2C1006016)

Received Apr 16, 2019 Revised Oct 28, 2019 Accepted Nov 11, 2019

Corresponding author: Song, Youngshin

College of Nursing, Chungnam National University

266 Munwha-ro, Jung-gu, Daejeon 35015, Korea

Tel: +82-42-580-8334, Fax: +82-42-580-8309, E-mail: yssong87@cnu.ac.kr 


\section{INTRODUCTION}

In diabetes mellitus (DM), unsuccessful glycemic control over a long period of time can cause diabetic neuropathy, peripheral vascular dysfunction, or occlusion, which can lead to diabetic foot [1]. The incidence of diabetic foot ulcers is approximately $2 \%$ per year, and the lifetime incidence for diabetic patients is 15 25\% [2]. 50 70\% of foot amputations are preceded by diabetic foot ulcers [3]. When the foot is amputated, there is a $60 \%$ chance of amputating the contralateral foot within five years, with the 5-year mortality rate around 40\% [4-6]. The likelihood of leg amputation for patients with DM is 10.1 times higher than for patients without DM, with a 7.8 times higher chance of developing diabetic foot complications [7]. Furthermore, the annual average total cost of treatment is 2 times higher for patients with DM, and the number of hospital days is 1.6 times higher than it is for patients without DM [7]. DM results in a high prevalence rate of diabetic foot complications, serious aftereffects such as amputation, long-term treatments, financial problems caused by high treatment costs, and social and psychological stress for patients and their families [8].

The prevalence rate and treatment costs of diabetic foot complications can be reduced by regular foot examinations, regular screening for prevention of diabetic foot ulcers, differentiation of high-risk patients, and lesion treatment; and additionally, the incidence of leg amputation can be decreased to $50 \%$ [1]. Accurate assessment is essential for precise identification of risk factors for foot ulcers, as well as for discerning high-risk groups and ensuring that ulcers do not lead to amputation [9]. Diabetic foot complications need to be managed in a way that monitors the present condition while also screening for risk factors early to prevent the patient from becoming highrisk for amputation [9]. Therefore, the use of standardized assessment tools for objectively evaluating and discerning diabetic foot complications is an important clinical practice.

Tools that were developed few decades ago for assessing diabetic foot complications include the Pressure Sore Status Tool (PSST) [10], Pressure Ulcer Scale for Healing (PUSH) [11], Wound Healing Scale (WHS) [12], Sussman Wound Healing Tool (SWHT) [13], and Bates-Jensen Wound Assessment Tool (BWAT) [14]. Unfortunately, these tools were designed to assess for wound change, not for early screening of diabetic foot complications such as preventive behavioral factors (i.e., regular skin check). Recently, they are not often used in clinics because the tools are complicated and cumbersome. On the other hand, the Wagner system [15] and the University of Texas Diabetic Wound
Classification [16] are used more frequently than tools introduced above because of they are easy to assess and simple. The Wagner system and University of Texas Diabetic Wound Classification can assess the ulcer depth and the presence of osteomyelitis or gangrene by using grading system from 0 to 5 for foot, but it is limited in identifying preventative behavior and early detection of foot changes needed to make a clinical judgment $[17,18]$.

Data that have been consistently well-researched using standardized assessment tools can be used to monitor changes in the patient and may be useful for communication between multi-disciplinary teams [19]. Despite the number of patients with DM that have suffered from diabetic foot complications, risk classification tables that can effectively screen for early cases of diabetic foot have been limited [8].

Due to the necessity of developing an assessment tool that can classify, predict, and evaluate diabetic foot complications, we conducted a literature review with the aim of systematically evaluating the psychometric properties of diabetic foot complication assessment tools. The specific goals of this study were a) to analyze the methodological characteristics and psychometric properties of the included assessment tools, and b) to classify the items of the assessment tools.

\section{METHODS}

\section{Study Design}

The study design was a systematic literature review of the contents and properties of diabetic foot assessment tools.

\section{Search Strategy}

The two authors independently searched for articles related to diabetic foot complication assessment tools that were published between 2007 and 2016 in the CINAHL Database, PubMed, Embase, and Cochrane Library Database. The clinical practice guidelines for the diabetic foot were revised in 2006 and several tools were developed to reflect the new guidelines, limiting the period of article extraction. The search terms of "diabetes mellitus" and "foot ulcer" were retrieved using the Boolean operators "and", "or", and "not". MeSH terms and synonyms were checked prior to performing the search.

\section{Inclusion Criteria and Exclusion Criteria}


Inclusion criteria were as follows: 1) the study included a standardized assessment tool for diabetic foot complications that was developed within the past 10 years, and 2) the publication was written in English. Exclusion criteria were as follows: 1 ) intervention studies and cohort studies were excluded; 2) publications such as dissertations, announcements, and independent volumes were excluded; and 3) tools that placed more importance on assessment for complications other than diabetic foot complications were excluded.

\section{Data Extraction and Evaluation}

The literature search was performed in two stages. First, the titles and abstracts were reviewed for relevancy to this study. Next, the full article was reviewed; if it matched the inclusion criteria, it was selected. A total of 8,096 results were found from the following: 1,085 results from Embase, 568 results from Cochrane Library CENTRAL, 3,557 results from PubMed and 2,886 results from CINAHL.
Endnote $X 7$ identified 1,841 duplicate results, which were excluded. The two researchers then reviewed the abstracts independently and selected relevant papers according to the inclusion criteria (studies that included tools to assess diabetic foot complications). In the process of checking the titles and abstracts, publications that were intervention studies, meta- or literature reviews, published more than 10 years ago, or mainly opinion articles were excluded. Accordingly, 6,143 results were excluded. In the second step, a review of the entire article, the authors excluded an additional 105 articles for reasons that included, among others, being written in a language other than English or not having included the assessment tool. Ultimately, a total of seven papers were selected. However, two of these papers included the same tool; therefore, the one that was published more recently was selected, leaving a final total of six tools. Two independent researchers conducted the literature search process. When there were differences in opinion, these were resolved through discussion between the researchers (Figure 1).

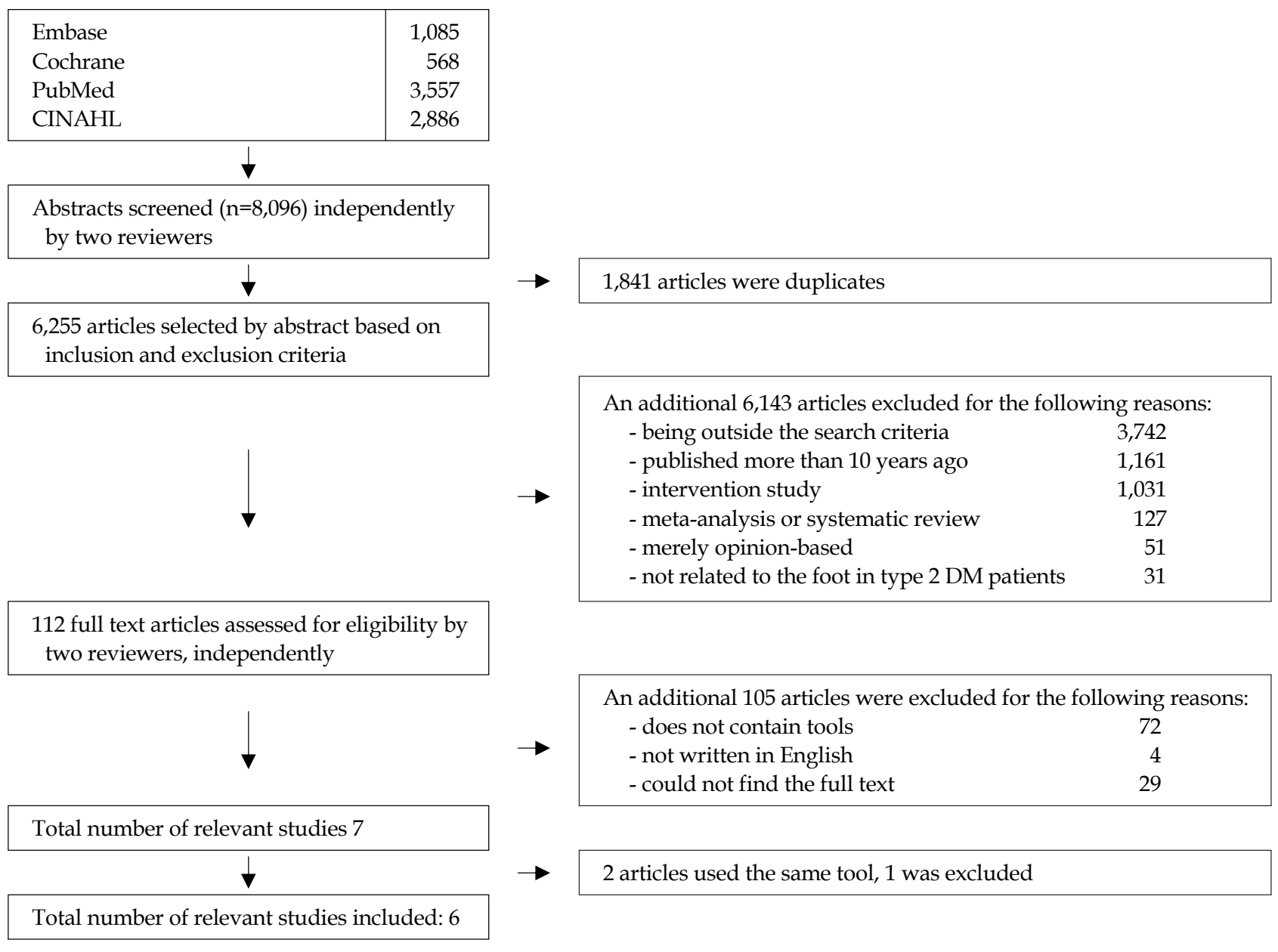

Figure 1. Flow chart of search process. 


\section{Ethical Considerations}

This study protocol was approved by Institutional Review Board (IRB No 2-1046881-A-N-01-201703-HR-007-09) of C-University.

\section{RESULTS}

\section{Methodological Characteristics}

A total of six tools were selected as standardized assessment tools used for diabetic foot complications: The Foot
Assessment Form, the revised version of Basic Foot Screening Checklist (BFSC), the Saint Elian Wound Score System (SEWSS), the United Kingdom Screening Test (UKST), Screening for the High-Risk Diabetic Foot: A 60-Second Tool, and the New DFU Assessment Scale (DFUAS).

The tools were developed between 2007 and 2016. By country, there was one tool each from the United States, Mexico, Australia, Nigeria, Tanzania, and Indonesia. These tools were all developed for type $2 \mathrm{DM}$ and were used to assess a population ranging from 52 to 1,266 patients. Methodological characteristics, including evaluation purpose and structures of items in each tool, are presented in Table 1.

Table 1. Methodological Characteristics of the Studies

\begin{tabular}{|c|c|c|c|c|c|}
\hline Name & $\begin{array}{c}\text { Year of } \\
\text { publication }\end{array}$ & Country & Target population & Purpose & Structure of scale \\
\hline $\begin{array}{l}\text { Foot assessment } \\
\text { form }\end{array}$ & 2008 & USA & $\begin{array}{l}52 \text { patients with type } \\
2 \text { DM with } \\
\text { diagnoses of } \\
\text { neuropathy, } \\
\text { peripheral vascular } \\
\text { disease, and foot } \\
\text { conditions }\end{array}$ & $\begin{array}{l}\text { To identify common } \\
\text { foot conditions }\end{array}$ & $\begin{array}{l}\text { 6-item (yes or no); Acute swelling } \\
\text { and/or deformity, skin breakdown } \\
\text { (ulcer), callus, digital deformity, } \\
\text { history of amputation/ulceration, } \\
\text { dystrophy nails and/or dry skin }\end{array}$ \\
\hline $\begin{array}{l}\text { Revised version } \\
\text { of Basic Foot } \\
\text { Screening } \\
\text { Checklist } \\
\text { (BFSC) }\end{array}$ & 2009 & Australia & $\begin{array}{l}500 \text { patients with } \\
\text { type } 2 \text { DM and } \\
\text { impaired glucose } \\
\text { tolerance }\end{array}$ & $\begin{array}{l}\text { To revise the BFSC } \\
\text { for use by } \\
\text { generalist health } \\
\text { professionals }\end{array}$ & $\begin{array}{l}\text { 7-item (yes or no); Ask the patient } \\
\text { (neuropathic symptoms, rest pain, } \\
\text { intermittent claudication, previous } \\
\text { foot ulcer, amputation), look at both } \\
\text { feet (infection, ulceration, calluses, } \\
\text { skin breaks, nail), pulse, test for } \\
\text { neuropathy (monofilament), } \\
\text { footwear, education need, self-care } \\
\text { capacity }\end{array}$ \\
\hline $\begin{array}{l}\text { Saint Elian } \\
\text { Wound Score } \\
\text { System } \\
\text { (SEWSS) }\end{array}$ & 2010 & Mexico & $\begin{array}{l}235 \text { patients, older } \\
\text { than } 18 \text { with type } 2 \\
\text { DM and diabetes } \\
\text { foot ulcer }\end{array}$ & $\begin{array}{l}\text { To validate the } \\
\text { checklist of } 10 \\
\text { wound factors }\end{array}$ & $\begin{array}{l}\text { 10-item (0 3 score); Location, } \\
\text { topographic aspects, affected zones, } \\
\text { ischemia, infection, edema, } \\
\text { neuropathy, depth, area, wound } \\
\text { healing phase }\end{array}$ \\
\hline $\begin{array}{l}\text { The United } \\
\text { Kingdom } \\
\text { Screening Test } \\
\text { (UKST) }\end{array}$ & 2010 & Nigeria & $\begin{array}{l}120 \text { with type } 2 \mathrm{DM} \\
\text { patients with and } \\
\text { without peripheral } \\
\text { neuropathy }\end{array}$ & $\begin{array}{l}\text { To evaluate the } \\
\text { effects of duration } \\
\text { of DM on } \\
\text { peripheral } \\
\text { neuropathy using } \\
\text { UKST }\end{array}$ & $\begin{array}{l}\text { - Symptom 5-item (total 0 9 score); } \\
\text { Abnormal sensation felt, site of } \\
\text { discomfort, time of worst symptom, } \\
\text { alleviating factor, night time } \\
\text { awakening } \\
\text { - Sign 4-item (total 0 10 score); Ankle } \\
\text { reflex, pain, vibration, temperature }\end{array}$ \\
\hline $\begin{array}{l}\text { Screening for the } \\
\text { High-Risk } \\
\text { Diabetic Foot: } \\
\text { A 60-Second } \\
\text { Tool (2012)(C) }\end{array}$ & 2012 & Tanzania & $\begin{array}{l}\text { 1,266 with type } 2 \text { DM } \\
\text { patients with } \\
\text { diabetes foot } \\
\text { complication }\end{array}$ & $\begin{array}{l}\text { To detect the } \\
\text { high-risk diabetic } \\
\text { foot }\end{array}$ & $\begin{array}{l}\text { 10-item (yes or no); Previous ulcer, } \\
\text { previous amputation, deformity, } \\
\text { absent pedal pulses, active ulcer, } \\
\text { ingrown toenail, calluses, blisters, } \\
\text { fissure, monofilament }\end{array}$ \\
\hline $\begin{array}{l}\text { The new DFU } \\
\text { assessment } \\
\text { scale (DFUAS) }\end{array}$ & 2016 & Indonesia & $\begin{array}{l}62 \text { with type } 2 \mathrm{DM} \\
\text { patients with } \\
\text { diabetes foot ulcer }\end{array}$ & $\begin{array}{l}\text { To evaluate the } \\
\text { concurrent validity, } \\
\text { construct validity } \\
\text { and predictive } \\
\text { validity of DFUAS } \\
\text { in Indonesia }\end{array}$ & $\begin{array}{l}\text { 11-item (total 0 98 score); Depth, size, } \\
\text { size score, inflammation/infection, } \\
\text { proportion of granulation tissue, } \\
\text { type of necrotic tissue, proportion of } \\
\text { necrotic tissue, proportion of slough, } \\
\text { maceration, type of wound edge, } \\
\text { tunneling }\end{array}$ \\
\hline
\end{tabular}




\section{Psychometric Properties}

The total number of tool items ranged from 6 to 11. To examine the psychometric properties, the validities and reliabilities were identified. Among the six tools, the Foot Assessment Form and UKST did not evaluate both reliability and validity (Table 2 ).
The BFSC and DFUAS evaluated validity by calculating the sensitivity ( $54 \%$ and $89 \%$, respectively), specificity $(77 \%$ and $71 \%$, respectively), and positive predictive value $(82 \%$ and $86 \%$, respectively). The BFSC and SEWSS calculated reliability by a Kappa test to verify inter-rater reliability. The k-values of the BFSC and SEWSS were .35 and .80, respectively. The DFUAS was reliable with an intra-class

Table 2. Psychometric Properties of Six Tools

\begin{tabular}{|c|c|c|c|c|c|c|c|}
\hline $\begin{array}{l}\text { Name of } \\
\text { instrument }\end{array}$ & $\begin{array}{l}\text { Number } \\
\text { of items }\end{array}$ & $\begin{array}{c}\text { Response } \\
\text { format }\end{array}$ & Scoring & Grading & Validity & Reliability & Cut off \\
\hline $\begin{array}{l}\text { Foot Assessment } \\
\text { form }\end{array}$ & 6 & Yes / No & $\begin{array}{l}\text { Check the } \\
\text { number of } \\
\text { 'yes' }\end{array}$ & $\begin{array}{l}\text { Any "Yes" response } \\
\text { requires follow up } \\
\text { or a referral to a } \\
\text { foot specialist }\end{array}$ & Not reported & Not reported & $\begin{array}{l}\text { Not } \\
\text { reported }\end{array}$ \\
\hline $\begin{array}{l}\text { Revised version } \\
\text { of Basic Foot } \\
\text { Screening } \\
\text { Checklist } \\
\text { (BFSC) }\end{array}$ & 7 & $\begin{array}{l}\text { Yes / No } \\
\text { (good/poor) }\end{array}$ & $\begin{array}{l}\text { Check the } \\
\text { number of } \\
\text { 'yes' }\end{array}$ & $\begin{array}{l}\text { Any "Yes" response } \\
\text { requires follow up } \\
\text { or a referral to a } \\
\text { foot specialist }\end{array}$ & $\begin{array}{l}\text { Sensitivity: } .54 \\
\text { Specificity: } .77 \\
\text { Positive } \\
\text { predictive } \\
\text { value:.82 }\end{array}$ & $\kappa=.35$ & $\begin{array}{l}\text { Not } \\
\text { reported }\end{array}$ \\
\hline $\begin{array}{l}\text { Saint Elian } \\
\text { Wound Score } \\
\text { System } \\
\text { (SEWSS) }\end{array}$ & 10 & $\begin{array}{l}3 \text { or } 4 \text { points } \\
\text { Likert scale }\end{array}$ & $\begin{array}{l}\text { Range: 5 30 } \\
\text { points }\end{array}$ & $\begin{array}{l}\leq 10 \text { (mild), } \\
11 \sim 20 \text { (moderate), } \\
21 \sim 30 \text { (severe) }\end{array}$ & Not reported & $\kappa=.80$ & $\begin{array}{l}\text { Not } \\
\text { reported }\end{array}$ \\
\hline $\begin{array}{l}\text { The United } \\
\text { Kingdom } \\
\text { Screening Test } \\
\text { (UKST) }\end{array}$ & 9 & $\begin{array}{l}2 \text { or } 3 \text { points } \\
\text { Likert scale }\end{array}$ & $\begin{array}{l}\text { - } 5 \text { symptoms: } \\
\text { overall } 9 \\
\text { points } \\
\text { - } 4 \text { signs: } \\
\text { overall } 10 \\
\text { points }\end{array}$ & $\begin{array}{l}\text { - } 5 \text { symptoms } \\
\text { grading: } \\
\text { 0 2 (normal), } \\
\text { 3 4 (mild PN), } \\
\text { 5 6 (moderate), } \\
\text { 7 9 (severe PN) } \\
\text { - 4 signs grading: } \\
\text { 0 2 (normal), } \\
\text { 3 5 (mild PN), } \\
\text { 6 8 (moderate PN), } \\
\text { 9 10 (severe PN) }\end{array}$ & Not reported & Not reported & $\begin{array}{l}\text { Not } \\
\text { reported }\end{array}$ \\
\hline $\begin{array}{l}\text { Screening for the } \\
\text { High-Risk } \\
\text { Diabetic Foot: a } \\
\text { 60-Second Tool } \\
\text { (2012)@ }\end{array}$ & 10 & Yes / No & $\begin{array}{l}\text { Check the } \\
\text { number of } \\
\text { 'yes' }\end{array}$ & $\begin{array}{l}\text { Any “Yes" response } \\
\text { requires follow up } \\
\text { or a referral to a } \\
\text { foot specialist }\end{array}$ & Not reported & $\mathrm{ICC}=.72 \sim .98$ & $\begin{array}{l}\text { Not } \\
\text { reported }\end{array}$ \\
\hline $\begin{array}{l}\text { The new DFU } \\
\text { assessment } \\
\text { scale (DFUAS) }\end{array}$ & 11 & $\begin{array}{l}4,5,6 \text { and } 10 \\
\text { points Likert } \\
\text { scale }\end{array}$ & $\begin{array}{l}\text { Range: } 0 \sim 98 \\
\text { points }\end{array}$ & $\begin{array}{l}\text { Higher scores } \\
\text { indicate } \\
\text { more severe wounds }\end{array}$ & $\begin{array}{l}\text { Concurrent } \\
\text { validity } \\
\text { BWAT r=.92 } \\
\text { PUSH r }=.87 \\
\text { Predictive } \\
\text { validity } \\
\text { Sensitivity: .89 } \\
\text { Specificity: .71 } \\
\text { Positive } \\
\text { predictive } \\
\text { value: } .86 \\
\text { Negative } \\
\text { predictive } \\
\text { value: } .77\end{array}$ & $\mathrm{ICC}=.98$ & $\begin{array}{l}\text { Cutoff } \\
\text { score }=12 \\
\text { AUC }=.90\end{array}$ \\
\hline
\end{tabular}

BWAT=Bates-Jensen Wound Assessment Tool; PUSH=Pressure Ulcer Scale for Healing; ICC=Intra-class correlation; AUC=Area Under the Curve; $\mathrm{PN}=$ peripheral neuropathy. 
correlation coefficient (ICC) of .98. Only the DFUAS suggested a cutoff score (i.e., 12), and the area under the curve (AUC) was .90.

The Foot Assessment Form, BFSA, and 60-second Tool used a dichotomous response format (yes/no), whereas the other three tools used a Likert scale.

\section{Contents of the Six Tools}

The subcategories of the tools included dermatologic, vascular, neurological, musculoskeletal, and current wound /ulcer changes. The high-frequency items in each subcategory were: ulcer, previous ulcer, and nail and calluses in the dermatology category; pedal pulse in the vascular category; sensation in the neurological category; previous amputation in the musculoskeletal category; and infection in the current wound/ulcer category. Among them, ulcers, previous ulcers, nail and calluses, previous amputation, sensation, and infection were identified as the most frequent items. Table 3 summarizes the contents of the six tools.

\section{DISCUSSION}

In this current review, the Foot Assessment Form, BFSC, SEWSS, UKST, Screening for the High-Risk Diabetic Foot: A 60-Second Tool (2012), and the DFUAS were found to assess the risk factors of diabetic foot. These six tools were developed for the diagnosis, prediction, and evaluation of diabetic foot. However, no single tool achieves all three purposes of diagnosis, prediction, and evaluation.

Screening for the High-Risk Diabetic Foot: A 60-Second Tool [20] was designed to be used within one minute for a quick and systematic foot screening. It has the advantage of being simple and quick to use; however, as a weakness, it allows for nothing more than a simple distinction of the current state of the foot. The DFUAS [17], developed in 2016, also only enables a distinction of the current state of foot complications. Although it is important to detect and manage risk factors early to prevent diabetic foot ulcers [9], six assessment tools have only been applied after the impairment has already occurred. Especially four tools (the Foot Assessment Form, BFSC, SEWSS and UKST) were used only in patients with diabetic foot complications.

The sample sizes for these six tools ranged from 52 to 1,266 patients. The number of target subjects for the Foot Assessment Form and DFUAS were less than 70. Tools that were developed with a small number of participants have limitations in their use because they have not sat- isfied the normal distribution. Furthermore, only one tool (the DFUAS) presented a cutoff score and psychometric properties in terms of reliability and validity. Two tools (the Foot Assessment Form and the UKST) did not evaluate psychometric properties (validity and reliability).

The response format varied for each tool. Three of the six tools used a dichotomous response format (yes/no questions), which indicated high risk when the answer was yes. A dichotomous classification has the weakness of enabling nothing more than a superficial assessment due to the difficulty in precisely assessing the current state [21]. This finding was consistent with a study [22] that pointed out that healthcare providers may overlook the risk of diabetic foot complications occurring in diabetic patients, which often leads to a missed window of time that is critical for treatment. Therefore, the tools that include a variety of information in terms of diabetic foot risk factors and a more detailed scoring system should be developed. Risk factors for diabetic foot complications include nerve damage and peripheral vascular diseases, and behavioral factors are secondary to infection, which results in amputation [23].

As such, various factors are related to diabetic foot, the most assessed items for each tool were foot ulcers, previous ulcers, nails and calluses, previous amputation, sensation, and infection, which is almost in line with the guidelines for the assessment of diabetic foot complications by the American Diabetes Association [23]. The advantage of all tools is that they can be used to assess patients easily and quickly, perform appropriate interventions, and prevent patients from unnecessary hospitalization or amputation through early diagnosis. Similar to skin wound assessment tools such as the PSST and PUSH, four tools focused on the physical signs and symptoms in the patient's current status. Only the BFSC and UKST included items that could assess educational needs and foot care capacities. The most reviewed tool did not reflect the behavioral factors for diabetic foot self-care. In clinical and community healthcare settings, diabetes educators have emphasized foot care to all patients with DM [24]. New guidelines published by the ADA in 2019 stated that "all patients with diabetes and their families should be provided general education about appropriate foot management and monitoring on a daily basis for surveillance of early foot problems"[24].

Based on this current review for diabetic foot assessment, various evaluations should be added to the existing tools, such as foot care practice and heath behaviors (e.g., smoking). Moreover, tools that contain diabetes self-management, including preventive behavioral factors as well 
Table 3. Contents in Six Tools

\begin{tabular}{|c|c|c|c|c|c|c|c|}
\hline Contents & Categories & $\begin{array}{c}\text { Foot } \\
\text { assessment } \\
\text { form }\end{array}$ & BFSC & SEWSS & UKST & $\begin{array}{l}\text { A 60-Second } \\
\text { Tool (2012) }\end{array}$ & DFUAS \\
\hline Dermatology & $\begin{array}{l}\text { Calluses } \\
\text { Blisters } \\
\text { Edema \& swelling } \\
\text { Epithelization \& maceration } \\
\text { Fissure } \\
\text { Granulation tissue } \\
\text { Ingrown toenail } \\
\text { Previous ulcer } \\
\text { Skin } \\
\text { Ulcer }\end{array}$ & $\begin{array}{l}0 \\
0 \\
0 \\
0\end{array}$ & $\begin{array}{l}0 \\
0 \\
0 \\
0\end{array}$ & $\bigcirc$ & & $\begin{array}{l}0 \\
0 \\
0 \\
0\end{array}$ & 0 \\
\hline Muscular-skeletal & $\begin{array}{l}\text { Deformity } \\
\text { Previous amputation }\end{array}$ & $\begin{array}{l}0 \\
0\end{array}$ & O & & & $\begin{array}{l}0 \\
0\end{array}$ & \\
\hline $\begin{array}{l}\text { Neurologic } \\
\text { change }\end{array}$ & $\begin{array}{l}\text { Ankle reflex } \\
\text { Monofilament } \\
\text { Pain-pin-pick } \\
\text { Sensation/Neuropathy } \\
\text { Vibration-128Hz }\end{array}$ & & 0 & $\bigcirc$ & $\begin{array}{l}0 \\
0 \\
0 \\
0\end{array}$ & 0 & \\
\hline $\begin{array}{l}\text { Current wound/ } \\
\text { ulcer }\end{array}$ & $\begin{array}{l}\text { Depth } \\
\text { Edges } \\
\text { Infection } \\
\text { Ischemia } \\
\text { Location (area) } \\
\text { Necrotic tissue } \\
\quad \text { Type } \\
\quad \text { Proportion } \\
\text { Proportion of slough } \\
\text { Size (size score) } \\
\text { Undermining \& tunneling }\end{array}$ & & ○ & $\begin{array}{c}0 \\
0 \\
0 \\
0(0)\end{array}$ & & & $\begin{array}{c}0 \\
0 \\
\bigcirc \\
(\bigcirc) \\
\bigcirc\end{array}$ \\
\hline Pain & $\begin{array}{l}\text { Discomfort } \\
\text { Night time awakening } \\
\text { Rest pain } \\
\text { Worst symptom }\end{array}$ & & O & & $\begin{array}{l}0 \\
0 \\
0\end{array}$ & & \\
\hline Others & $\begin{array}{l}\text { Affected zones } \\
\text { Alleviating factor } \\
\text { Educational needs } \\
\text { Footwear } \\
\text { Self-care capacity } \\
\quad \text { Topographic aspects } \\
\text { Wound healing phase }\end{array}$ & & $\begin{array}{l}0 \\
0 \\
0\end{array}$ & $\bigcirc$ & $\bigcirc$ & & \\
\hline
\end{tabular}

BFSC=basic foot screening checklist; SEWSS=Saint Elian Wound Score System; UKST=The United Kingdom Screening Test; DFUAS=The new DFU Assessment Scale.

as physical risk symptoms and signs, should be required. This study is significant because previously developed assessment tools for diabetic foot complications were systemically examined. By determining the characteristics and usefulness of each tool, the results of this study can guide the future development of assessment tools for foot complications. 


\section{CONCLUSION}

Accurate diabetic foot assessment is important to determine high-risk individuals, as well as to prevent existing ulcers from worsening and requiring amputation. Healthcare providers should educate patients with DM on appropriate foot care and perform foot inspections at every visit, regardless of their level of risk for foot ulcers and amputations. In future study, multidimensional assessment tools including physical risk factors as well as behavioral risk factors related to diabetic foot complications should be developed based on the findings from this integrative review.

\section{REFERENCES}

1. Frykberg RG, Zgonis T, Armstrong DG, Driver VR, Giurini JM, Kravitz SR, et al. Diabetic foot disorders: a clinical practice guideline (2006revision). The Journal of Foot and Ankle Surgery. 2006;45(5):S1-S66. https://doi.org/10.1016/S1067-2516(07)60001-5

2. Armstrong DG, Boulton AJM, Bus SA. Diabetic foot ulcers and their recurrence. New England Journal of Medicine. 2017;376: 2367-2375

https://doi.org/10.1056/NEJMra1615439

3. Jones NJ, Harding K. 2015 International Working Group on the Diabetic Foot Guidance on the prevention and management of foot problems in diabetes. International Wound Journal. 2015; 12(4):373-374. https://doi.org/10.1111/iwj.12475

4. Neville RF, Sidawy AN. Surgical bypass: when is it best and do angiosomes play a role?. Seminars in Vascular Surgery. 2012; 25(2):102-107.

https://doi.org/10.1053/j.semvascsurg.2012.04.001

5. Morbach S, Furchert H, Groblinghoff U, Hoffmeier H, Kersten $\mathrm{K}$, Klauke GT, et al. Long-term prognosis of diabetic foot patients and their limbs: amputation and death over the course of a decade. Diabetes Care. 2012;35(10):2021-2027. https://doi.org/10.2337/dc12-0200

6. Jupiter DC, Thorud JC, Buckley CJ, Shibuya N. The impact of foot ulceration and amputation on mortality in diabetic patients. I: from ulceration to death, a systematic review. International Wound Journal. 2016;13(5):892-903.

https://doi.org/10.1111/iwj.12404

7. Park IB, Kim J, Kim DJ, Chung CH, Oh JY, Park SW, et al. Diabetes epidemics in Korea: reappraise nationwide survey of diabetes. Diabetes and Metabolism Journal. 2013;37(4):233-239. https://doi.org/10.4093/dmj.2013.37.4.233

8. Kerr M, Barron E, Chadwick P, Evans T, Kong WM, Rayman G, et al. The cost of diabetic foot ulcers and amputations to the
National Health Service in England. Diabetic Medicine. 2019; 36(8):995-1002. https://doi.org/10.1111/dme.13973

9. Lee HS. Prevention and management of the diabetic foot. Journal of the Korean Medical Association. 2013;56(3):220-228. https://doi.org/10.5124/jkma.2013.56.3.220

10. Pillen H, Miller MD, Thomas JM, Puckridge P, Sandison S, Spark JI. Assessment of wound healing: validity, reliability and sensitivity of available instruments. Wound Practice and Research. 2009;17(4):208-215.

11. Thomas DR, Rodeheaver GT, Bartolucci AA, Franz RA, Sussman C, Ferrell BA, et al. Pressure ulcer scale for healing: derivation and validation of the PUSH tool. The PUSH task force. Advances in wound care: The Journal for Prevention and Healing. 1997;10(5):96-101.

12. Krasner D. Wound Healing Scale, version 1.0: a proposal. Advances in wound care. The Journal for Prevention and Healing. 1997;10(5):82-85.

13. Sussman C, Swanson G. Utility of the Sussman wound healing tool in predicting wound healing outcomes in physical therapy. Advances in Skin and Wound Care. 1997;10(5):74-77.

14. Harris C, Bates-Jensen B, Parslow N, Raizman R, Singh M, Ketchen R. Bates-Jensen wound assessment tool: pictorial guide validation project. Journal of Wound Ostomy and Continence Nursing. 2010;37(3):253-259.

https://doi.org/10.1097/WON.0b013e3181d73aab

15. Wagner Jr FW. The dysvascular foot: a system for diagnosis and treatment. Foot and Ankle international. 1981;2(2):64-122. https://doi.org/10.1177/107110078100200202

16. Armstrong DG, Lavery LA, Harkless LB. Validation of a diabetic wound classification system: the contribution of depth, infection, and ischemia to risk of amputation. Diabetes Care. 1998;21(5):855-859. https://doi.org/10.2337/diacare. 21.5.855

17. Arisandi D, Oe M, Roselyne Yotsu R, Matsumoto M, Ogai K, Nakagami G, et al. Evaluation of validity of the new diabetic foot ulcer assessment scale in Indonesia. Wound Repair and Regeneration. 2016;24(5):876-884.

https://doi.org/10.1111/wrr.12464

18. Karthikesalingam A, Holt P, Moxey P, Jones K, Thompson M, Hinchliffe R. A systematic review of scoring systems for diabetic foot ulcers. Diabetic Medicine. 2010;27(5):544-549. https://doi.org/10.1111/j.1464-5491.2010.02989.x

19. Jeong IS, Park KH, Song BR, Sim KH, Han EJ, Hong EY, et al. Development of clinical practice guideline by adaptation: diabetic foot care. Journal of Korean Clinical Nursing Research. 2015;21(2):196-206

https://doi.org/10.22650/JKCNR.2015.21.2.196

20. Sibbald R, Ayello E, Alavi A, Ostrow B, Lowe J, Botros M, et al. Screening for the high-risk diabetic foot: a 60-second tool $(2012)^{\odot}$. Advances in Skin and Wound Care. 2012;25:465-476. https://doi.org/10.1097/01.asw.0000421460.21773.7b 
21. Jenniskens K, Naaktgeboren CA, Reitsma JB, Hooft L, Moons KGM, van Smeden M. Forcing dichotomous disease classification from reference standards leads to bias in diagnostic accuracy estimates: A simulation study. Journal of Clinical Epidemiology. 2019;111:1-10.

https://doi.org/10.1016/j.jclinepi.2019.03.002

22. Suh HS, Hong JP. Diabetic foot ulcer. Journal of The Korean Medical Association. 2015;58(9):795-800.

https://doi.org/10.5124/jkma.2015.58.9.795
23. American Diabetes Association. Standards of medical care in diabetes-2015 abridged for primary care providers. Clinical Diabetes: A Publication of The American Diabetes Association. 2015;33(2):97-111.

https://doi.org/10.2337/diaclin.33.2.97

24. American Diabetes Association. 11. Microvascular complications and foot care: standards of medical care in diabetes-2019. Diabetes Care. 2019;42(1):S124-S138.

https://doi.org/10.2337/dc19-S014 